\title{
Insecticidal efficiency of native plant extracts against whitefly (Bemasia tabaci) on cotton crop
}

\author{
Narjis Ashfaq ${ }^{1}$, Muhammad Amjad Bashir ${ }^{*}$, Mamoona Noreen ${ }^{3}$, \\ Naveed Jameel ${ }^{1}$, Azra Ayoub ${ }^{3}$ and Abdul Latif ${ }^{1}$ \\ 1. Sangtani, Women Rural Development Organization, Rajan Pur-Pakistan \\ 2. Department of Plant Protection faculty of Agricultural Sciences Ghazi University Dera Ghazi Khan Punjab- \\ Pakistan \\ 3. Department of Zoology The Women University Multan Punjab-Pakistan \\ *Corresponding author's email: abashir@gmail.com
}

Citation

Narjis Ashfaq, Muhammad Amjad Bashir, Mamoona Noreen, Naveed Jameel, Azra Ayoub and Abdul Latif. Insecticidal efficiency of native plant extracts against whitefly (Bemasia tabaci) on cotton crop. Pure and Applied Biology. Vol. 8, Issue 1, pp727-732. http://dx.doi.org/10.19045/bspab.2019.80014

\begin{tabular}{llll}
\hline \hline Received: 01/11/2018 & Revised: 11/01/2019 & Accepted: 16/01/2019 & Online First: 25/01/2019 \\
\hline \hline
\end{tabular}

\section{Abstract}

Cotton is one of the major cash crops of Pakistan. A collaborative study was conducted by Sangtani Women Development Organization, Ghazi University Dera Ghazi Khan and Women University Multan under Better Cotton Initiative project to provide an eco-friendly and economical control of white fly, aphid, jassid and thrips. For this purpose, ten locally available leaves of the plant trees were selected and their extracts were made with the help of methanol. White fly population is studied and when it's reached at Economic Threshold Level, the extract of plant leaves were sprayed at 2\%, 4\% and 6\% concentration. The data was taken after 24, 48 and 72 hours of spray to check the efficiency of different plant extracts at different concentration. After data analysis result were incorporated and our results shows that And when the data of these tested plants were analysis, it is clear from our data that at $2 \%$ concentration all tested plants extract showed good potential as an insecticide against Bemasia tabaci but among these Delbergia sissoo showed excellent mortality rate of $B$. tabaci When these plants were tested at $4 \%$ concentration then our results reflect that Melia azedarach and Eculypatus camaldulensis are most effective against $B$. tabaci and at $6 \%$ concentration Calotropis gigantean, Melia azedarach and E. camaldulensis have the most effective insecticidal effect against adult population of the white fly of cotton crop followed by Accaia nilotica and Black serruss. Plant extract have the potential to become an integral part of Integrated Pest management (IPM) as a repellent and as well as an insecticide.

Keyword: Eco-friendly control; Insecticides; IPM; Plant extracts; White fly

\section{Introduction}

Insects are the arthropods that exhibit wide range of habitats and living forms. They have successful evolutionary history due to their extensive adaptations to the environment (Reference please). Mostly plants act as host for insects. Monophagous insects feed on one plant species while others are poly-phagous which developed a variety of habitats and hosts [1]. One of the most common hosts of insects is cotton (Gossypium hirsutum L.) which is widely cultivated crop all over the world. It is also known as "white gold" or cash crop of Pakistan. It added a remarkable value about $8.2 \%$ in agriculture and round about $3.2 \%$ in 
gross domestic product (GDP). Two thirds of Pakistan's earnings depends upon the export of cotton products, mostly through textiles that adds round $\$ 2.5$ billion in the country earning; while hundreds of textile mills and ginning factories are hugely depending upon cotton cultivation [2].

There are many factors responsible for low cotton yield but insects are ranked at the top of biotic agents that not only deteriorate the quality of cotton but also reduce the yield [3]. To control such harmful insect pests, farmers mostly use synthetic or naturallyoccurring pesticides [4].

Pesticides can produce positive effect on the regulation of plant's growth. More than one thousand pesticides are available in market which contains different formulations with maximum biological activity [5]. Today, all types of agricultural production mostly hinge on the pesticides; definitely, it is an extensive and renowned method for insect pest management which makes it central part of an agriculture system [6]. Man-made chemicals prove to be very effective because they quickly and easily help the farmers to get best results against the common pests otherwise they are ready for the reduction in crop yield. Even though the pest management techniques are still successful but these make insects more resistant to save their lives and upcoming generations [3].

Most of the synthetic pesticides contain chemicals which are harmful for humans and the environment but they can easily overcome insect pests and disease-causing organisms and increase crop yield $[7,8]$. In other words, it is continuously playing its role in IPM, because pesticide benefits are high or there are no practical alternatives [9]. A major threat to human health and environment is the non-judicious use of pesticides. The pesticide exposure in developing countries is major risk to farmers. The World Health Organization
(WHO) and United Nations Environmental Program (UNEP) have projected in developing countries that one out of five million patients is affected with pesticide poisoning while working on crop cultivation each year [10].

Natural Pesticide products have been emerging tool for many scientists to minimize the problems produced by harmful pesticides [11]. So, to minimize such issues, there is a need to explore bio-pesticides that are biodegradable, environmentally safe, selective, economical and compatible with IPM programs. Bio-pesticides consist of natural products which are cheaper as compared to synthetic pesticides. Biopesticides are known to contain secondary metabolites such as alkaloids, phenolics, terpenoids and some secondary minor chemicals. These botanical products can be taken as an alternative to chemical pesticides [12]. This will be very helpful in minimizing the undesirable side effects of synthetic pesticides and ultimately environmental pollution will be minimized. This study will open the windows for researchers, farmers and other community related to the cotton crop for growing organic cotton with low inputs and better yield

\section{Materials and methods Experimental site}

Field trials were conducted in the farmers' field of the community of Sangtani Women Rural Development Organization during the cropping season of 2018-19 in the District Rajan pur, Punjab, Pakistan under Better Cotton Initiative Project.

\section{Experimental materials}

Seed and other agronomic inputs material of the cotton crop was procured from the local market of the Rajan pur city, while plant extracts were obtained by collecting leaves from farmers' field and methyl alcohol was purchased from Multan Punjab Pakistan.

\section{Agronomic practices}


Plot size of 108 square feet was used for the growing of the cotton crop. A total of fifty plants per plot were cultivated. The cotton seeds were planted three (2) seeds per hole. Weeding and thinning was carried out exactly two (2) week after germination. The experiment was laid out in a Randomized Complete Block Design (RCBD) with 33 treatments having (10) plant extracts with three different concentrations $(2 \%, 4 \%$ \& $6 \%$ ) and Control for each concentration (Table 1).

\section{Preparation of plant extracts}

Leaves were collected from locally available trees near field and dried in shed area without direct sun contact. Dried leaves weighing $250 \mathrm{~g}$ for each plant (Table 1) were used to make powder with the help of grinder. The powder of each plant leaves was dissolved in $500 \mathrm{ml}$ of methanol, mixed thoroughly and left for 24 hours. The aqueous solution was filtered, using muslin cloth and the extracts were kept in a refrigerator as stock solution.

Table 1. Plant extract used and spray calculation

\begin{tabular}{|c|c|c|c|c|c|c|c|}
\hline T & $\begin{array}{c}\text { Local } \\
\text { Name }\end{array}$ & Botanical Name & $\begin{array}{c}\text { Concentration } \\
\text { Used (\%) }\end{array}$ & $\begin{array}{c}\text { Plot size } \\
\text { (sq feet) }\end{array}$ & $\begin{array}{c}\text { plant/ } \\
\text { plot }\end{array}$ & $\begin{array}{c}\text { Water } \\
\text { quantity } \\
\text { required }\end{array}$ & $\begin{array}{c}\text { Extract quantity } \\
\text { required }\end{array}$ \\
\hline T1 & Saraian & Black serruss & $2,4 \& 6$ & 108 & 50 & $625 \mathrm{ml}$ & $12.5+25+37.5=75 \mathrm{ml}$ \\
\hline T2 & Kikar & Accaia nilotica & $2,4 \& 6$ & 108 & 50 & $625 \mathrm{ml}$ & $12.5+25+37.5=75 \mathrm{ml}$ \\
\hline T3 & Jaman & Salvadora oleoides & $2,4 \& 6$ & 108 & 50 & $625 \mathrm{ml}$ & $12.5+25+37.5=75 \mathrm{ml}$ \\
\hline T4 & AK & Calotropis gigantea & $2,4 \& 6$ & 108 & 50 & $625 \mathrm{ml}$ & $12.5+25+37.5=75 \mathrm{ml}$ \\
\hline T5 & Bakain & Melia azedarach & $2,4 \& 6$ & 108 & 50 & $625 \mathrm{ml}$ & $12.5+25+37.5=75 \mathrm{ml}$ \\
\hline T6 & Neem & Azadirachta indica & $2,4 \& 6$ & 108 & 50 & $625 \mathrm{ml}$ & $12.5+25+37.5=75 \mathrm{ml}$ \\
\hline T7 & Euclaptus & $\begin{array}{c}\text { Euclyptus } \\
\text { camaldulensis }\end{array}$ & $2,4 \& 6$ & 108 & 50 & $625 \mathrm{ml}$ & $12.5+25+37.5=75 \mathrm{ml}$ \\
\hline T8 & Jaal & Salvadora oleoides & $2,4 \& 6$ & 108 & 50 & $625 \mathrm{ml}$ & $12.5+25+37.5=75 \mathrm{ml}$ \\
\hline T9 & $\begin{array}{c}\text { Konocarp } \\
\text { us }\end{array}$ & $\begin{array}{c}\text { Conocarpus } \\
\text { lancifolius }\end{array}$ & $2,4 \& 6$ & 108 & 50 & $625 \mathrm{ml}$ & $12.5+25+37.5=75 \mathrm{ml}$ \\
\hline T10 & Shesham & Dalbergia sissoo & $2,4 \& 6$ & 108 & 50 & $625 \mathrm{ml}$ & $12.5+25+37.5=75 \mathrm{ml}$ \\
\hline T11 & Control & \multicolumn{7}{|c|}{ Each treatment have three replications } & $625 \mathrm{ml}$ & \\
\hline
\end{tabular}

\section{Application of plant extracts}

From the stock solution, $250 \mathrm{ml}$ of each of the solution was diluted with $625 \mathrm{ml}$ of water to get $2 \%, 4 \%$ and $6 \%$ concentration. The control (unsprayed plots) was included for comparison. Foliar application was done using manually operated hand sprayers. The treatments were applied in the morning to prevent photodecomposition of the extracts.

\section{Sampling or pest scouting of $B$. tabaci}

\section{Data collection and data analysis}

Data were collected on population of white fly. Data collected were subjected to analysis of variance (ANOVA) using Randomized Complete Block Design (R C B D) as explained by Gomez and Gomex (1987). Means were compared using Duncan
Multiple Range test (DMRT) at $5 \%$ probability level.

\section{Results}

The results of the current study were incorporated after statistical analysis of the data of the tested ten locally available plant extracts at three different percentages $(2,4$ \& 6\%). According to our results, $2 \%$ concentration of all tested plants extracts showed good potential as an insecticide against B. tabaci. Among 10 plant extracts, $D$. sissoo greatly reduced the population of B. tabbaci with 0.00 mean value followed by $C$. lancifolius, E. cameldulensis and C.s gigantean with $0.02,0.09$ and 0.12 mean values, respectively. While the least control was obtained by Black serruss with 0.34 mean. Moreover, from our results it is clear 
that $2 \%$ concentration provide good mortality after 24 hours as compared to 48 and 72 hour data (Table 2).

At $4 \%$ concentration, results revealed that M. azedirach and E. cameldulensis are most effective against $B$. tabaci with 0.01 mean followed by A. nilotica, A. indica and Black serruss with 0.04, 0.05 and 0.06 mean respectively while $S$. oleiodes and $C$. lancifolious were least effective against the pest with 0.29 and 0.30 mean respectively (Table 3).

Table 2. Effect of plant extracts on Bemasia tabaci population at $2 \%$ concentration

\begin{tabular}{|c|c|c|c|c|c|}
\hline Treatment & Pre- Spray & $\mathbf{2 4}$ hours & $\mathbf{4 8}$ hours & $\mathbf{7 2}$ hours & Mean \\
\hline Control & $0.30 \mathrm{a}$ & $0.29 \mathrm{a}$ & $0.24 \mathrm{a}$ & $0.30 \mathrm{a}$ & \\
\hline Black serruss & $0.27 \mathrm{ab}$ & $0.12 \mathrm{ab}$ & $0.16 \mathrm{bc}$ & $0.20 \mathrm{ab}$ & $0.34 \pm 0$ \\
\hline Accaia nilotica & $0.28 \mathrm{a}$ & $0.12 \mathrm{ab}$ & $0.18 \mathrm{ab}$ & $0.18 \mathrm{a}$ & $0.16 \pm 0$ \\
\hline Salvadora oleoides & $0.23 \mathrm{ab}$ & $0.11 \mathrm{~b}$ & $0.06 \mathrm{~cd}$ & $0.23 \mathrm{ab}$ & $0.13 \pm 3$ \\
\hline Calotropis gigantea & $0.12 \mathrm{c}$ & $0.00 \mathrm{c}$ & $0.00 \mathrm{~d}$ & $0.12 \mathrm{c}$ & $0.04 \pm 0$ \\
\hline Melia azedarach & $0.10 \mathrm{c}$ & $0.00 \mathrm{c}$ & $0.00 \mathrm{~d}$ & $0.10 \mathrm{c}$ & $0.03 \pm 3$ \\
\hline Azadirachta indica & $0.18 \mathrm{bc}$ & $0.07 \mathrm{c}$ & $0.00 \mathrm{~d}$ & $0.18 \mathrm{bc}$ & $0.13 \pm 0$ \\
\hline Euclyptus camaldulensis & $0.09 \mathrm{c}$ & $0.00 \mathrm{c}$ & $0.00 \mathrm{~d}$ & $0.09 \mathrm{c}$ & $0.03 \pm 0$ \\
\hline Salvadora oleoides & $0.29 \mathrm{a}$ & $0.11 \mathrm{~b}$ & $0.05 \mathrm{c}$ & $0.00 \mathrm{~d}$ & $0.13 \pm 1$ \\
\hline Conocarpus lancifolius & $0.24 \mathrm{ab}$ & $0.00 \mathrm{c}$ & $0.00 \mathrm{c}$ & $0.05 \mathrm{~cd}$ & $0.02 \pm 1$ \\
\hline Dalbergia sissoo & $0.28 \mathrm{ab}$ & $0.00 \mathrm{c}$ & $0.00 \mathrm{~d}$ & $0.00 \mathrm{~d}$ & $0.00 \pm 0$ \\
\hline
\end{tabular}

Mean followed by the same alphabets in a column are not significantly different $(\mathrm{p}<0.05)$

Table 3. Effect of plant extracts on Bemasia tabaci population at $4 \%$ concentration

\begin{tabular}{|c|c|c|c|c|c|}
\hline Treatments & Pre Spray & $\mathbf{2 4}$ hours & $\mathbf{4 8}$ hours & $\mathbf{7 2}$ hours & Mean $\pm_{\text {_Sd }}$ \\
\hline & $0.24 \mathrm{c}$ & $0.19 \mathrm{c}$ & $0.19 \mathrm{a}$ & $0.27 \mathrm{a}$ & \\
\hline Black serruss & $0.16 \mathrm{ab}$ & $0.06 \mathrm{abc}$ & $0.01 \mathrm{a}$ & $0.00 \mathrm{~d}$ & $0.06 \pm 3$ \\
\hline Accaia nilotica & $0.19 \mathrm{a}$ & $0.04 \mathrm{ab}$ & $0.02 \mathrm{a}$ & $0.00 \mathrm{~d}$ & $0.05 \pm 1$ \\
\hline Salvadora oleoides & $0.12 \mathrm{bc}$ & $0.06 \mathrm{bc}$ & $0.00 \mathrm{a}$ & $0.04 \mathrm{~cd}$ & $0.07 \pm 3$ \\
\hline Calotropis gigantea & $0.17 \mathrm{a}$ & $0.09 \mathrm{~d}$ & $0.03 \mathrm{a}$ & $0.00 \mathrm{~d}$ & $0.07 \pm 3$ \\
\hline Melia azedarach & $0.15 \mathrm{ab}$ & $0.00 \mathrm{~d}$ & $0.00 \mathrm{a}$ & $0.04 \mathrm{~cd}$ & $0.01 \pm 3$ \\
\hline Azadirachta indica & $0.19 \mathrm{a}$ & $0.05 \mathrm{~cd}$ & $0.00 \mathrm{a}$ & $0.01 \mathrm{~d}$ & $0.05 \pm 3$ \\
\hline Euclyptus camaldulensis & $0.14 \mathrm{bc}$ & $0.00 \mathrm{~d}$ & $0.00 \mathrm{a}$ & $0.04 \mathrm{~cd}$ & $0.01 \pm 1$ \\
\hline Salvadora oleoides & $0.24 \mathrm{a}$ & $0.16 \mathrm{ab}$ & $0.11 \mathrm{abc}$ & $0.05 \mathrm{a}$ & $0.29 \pm 1$ \\
\hline Conocarpus lancifolius & $0.19 \mathrm{a}$ & $0.19 \mathrm{ab}$ & $0.13 \mathrm{ab}$ & $0.57 \mathrm{a}$ & $0.30 \pm 1$ \\
\hline Dalbergia sissoo & $0.10 \mathrm{a}$ & $0.11 \mathrm{bc}$ & $0.09 \mathrm{bc}$ & $0.00 \mathrm{a}$ & $0.14 \pm 0$ \\
\hline
\end{tabular}

And when the data of these tested at $6 \%$ plants extracts were analyzed, it is clear that $C$. gigantean, $M$. azedarach and $E$. camaldulensis have the most effective insecticidal effect against adult population of the white fly of cotton crop followed by A. nilotica and Black serruss (Table 4)..
Moreover, from our data it is also clear that at this concentration is effective after 24,28 and 72 hours, which may indicate that these plant extracts are not only repellent only. These plant extracts have great potential as an insecticide against white fly for cotton pest at this concentration. 
Table 4. Effect of plant extracts on Bemasia tabaci population at $6 \%$ concentration

\begin{tabular}{|c|c|c|c|l|c|}
\hline Treatments & Pres Spray & After 24hours & $\mathbf{4 8}$ hours & $\mathbf{7 2}$ hours & Mean \\
\hline Control & $0.19 \mathrm{a}$ & $0.19 \mathrm{a}$ & $0.17 \mathrm{a}$ & $0.19 \mathrm{a}$ & \\
\hline Black serruss & $0.11 \mathrm{ab}$ & $0.03 \mathrm{ab}$ & $0.03 \mathrm{bc}$ & $0.03 \mathrm{a}$ & $.03 \pm 1$ \\
\hline Accaia nilotica & $0.16 \mathrm{a}$ & $0.01 \mathrm{~cd}$ & $0.04 \mathrm{bc}$ & $0.06 \mathrm{~b}$ & $.04 \pm 1$ \\
\hline Salvadora oleoides & $0.11 \mathrm{ab}$ & $0.04 \mathrm{ab}$ & $0.00 \mathrm{~d}$ & $0.00 \mathrm{~d}$ & $0.1 \pm 3$ \\
\hline Calotropis gigantea & $0.13 \mathrm{ab}$ & $0.00 \mathrm{~b}$ & $0.00 \mathrm{c}$ & $0.00 \mathrm{~d}$ & $0.00 \pm 1$ \\
\hline Melia azedarach & $0.06 \mathrm{ab}$ & $0.00 \mathrm{~b}$ & $0.00 \mathrm{c}$ & $0.02 \mathrm{a}$ & $0.01 \pm 2$ \\
\hline Azadirachta indica & $0.09 \mathrm{ab}$ & $0.03 \mathrm{~b}$ & $0.00 \mathrm{c}$ & $0.05 \mathrm{a}$ & $0.04 \pm 1$ \\
\hline $\begin{array}{c}\text { Euclyptus } \\
\text { camaldulensis }\end{array}$ & $0.05 \mathrm{~b}$ & $0.00 \mathrm{~b}$ & $0.00 \mathrm{c}$ & $0.04 \mathrm{~b}$ & $0.01 \pm 3$ \\
\hline Salvadora oleoides & $0.18 \mathrm{a}$ & $0.10 \mathrm{ab}$ & $0.10 \mathrm{ab}$ & $0.10 \mathrm{ab}$ & $0.1 \pm 1$ \\
\hline Conocarpus & $0.17 \mathrm{a}$ & $0.10 \mathrm{ab}$ & $0.10 \mathrm{ab}$ & $0.10 \mathrm{ab}$ & $0.1 \pm 1$ \\
\hline Dalbergia sissoo & $0.10 \mathrm{ab}$ & $0.10 \mathrm{ab}$ & $0.10 \mathrm{ab}$ & $0.10 \mathrm{ab}$ & $0.1 \pm 1$ \\
\hline
\end{tabular}

Mean followed by the same alphabet in a column are not significantly different $(\mathrm{p}<0.05)$

\section{Discussion}

Almost it is common that the control treatment which remained unsprayed have much population as compare to treated one. The tested plants $B$. serruss, A. nilotica, $S$. oleoides, C. gigantean, M. azedarach, A. indica, E. camaldulensis, S. oleoides, $C$. lancifolius and $D$. sissoo effectively and efficiently controlled the sucking pest of cotton crop at all levels. The tested plants leaves extracts shows their insecidal efficiency against sucking pest complex of cotton and other crops by many other authors [14-16].

Similarly, D. sissoo controlled the insect pest of the cotton crop at the lowest concentration after 24 hours. The high effectiveness of $D$. sissoo could be because of its repellency and may be to its knock down effect on target organism [17]. Also the synergistic effect of plant materials enhanced its effectiveness thereby alleviating the population of the insect pest of cotton crop. This correlate with the work of Adebayo 2003, who reported that biopesticides, plant material were more effective than using Lambda cylothrin at recommended rate. This finding indicates the possibility of reducing the amount of synthetic insecticides that will go into the ecosystem when botanicals are incorporated.

The extracts of the different plant material which were tested at different levels controlled the insect pest of cotton and show their effectiveness after 24, 48 and 72 hours of spray this agrees with work of Adebayo (2003) that $T$. vogelii effectively controlled Bemasia species on cotton.

Use of botanicals in pest management of white gold i.e. cotton can help the farmers to reduce the sole reliance on synthetic insecticides. Moreover, these eco-friendly approaches of pest control with minimum disturbance to beneficial insects and non target organisms should be highly encouraged.

\section{Conclusion}

It is concluded through present investigation that the population of Bemasia tabaci was effected by using cotton. Among different plant extracts, $C$. gigantea and $M$. azedarach were observed much effective and such effect was observed maximum until 72 hrs after its application. Therefore, it is strongly suggested that the use of these local bio products, which are not only cheaper but also effective for the control of white fly on cotton crop. Further, they will also play a crucial role being safe bio pesticides for human, birds and natural enemies.

\section{Authors' contributions}

Conceived and designed the experiments: MA Bashir, N Ishfaq \& M Noreen, Performed the experiments: A Ayoub, N Jamal \& A Latif, Analyzed the data: MA Bashir, M Noreen, 
Contributed materials/ analysis/ tools: N Ishfaq \& A Ayoub, Wrote the paper: MA Bashir, A Ayoub, N Jamal \& A Latif.

\section{Acknowledgements}

We acknowledge all our research work to the Sangtani Women Rural Development Organization (SWRDO) and Better Cotton Initiative (BCI) Pakistan Rajan pur project for all moral, financial and all kind of support during this research.

\section{Refrences}

1. Raine NE (2018). An alternative to controversial pesticides still harms bumblebees.

2. Khalil H, Raza ABM, Afzal M, Aqueel M A, Khalil M S \& Mansoor MM (2017). Effects of plant morphology on the incidence of sucking insect pests' complex in few genotypes of cotton. $J$ of the Saudi Soc of Agri Sci 16(4): 344-349.

3. Rehman A, Jingdong L, Chandio A A, Hussain I, Wagan, SA \& Memon, QUA (2016). Economic perspectives of cotton crop in Pakistan: A time series analysis (Part 1). J of the Saudi Soc of Agri Sci (1970-2015).

4. Gesesew HA, Woldemichael K, Massa D \& Mwanri L (2016). Farmers Knowledge, Attitudes, Practices and Health Problems Associated with Pesticide Use in Rural Irrigation Villages, Southwest Ethiopia. PloS One 11(9): e0162527.

5. Chen R, Huang J, \& Qiao F. (2013). Farmers' knowledge on pest management and pesticide use in $\mathrm{Bt}$ cotton production in china. China Econ Rev 27: 15-24.

6. Negatu B, Kromhout H, Mekonnen Y \& Vermeulen R (2016). Use of Chemical Pesticides in Ethiopia: a cross-sectional comparative study on Knowledge, Attitude and Practice of farmers and farm workers in three farming systems. The Ann of Occup Hygi 60(5): 551-566.

7. Abbassy MMS (2017). Farmer's Knowledge, Attitudes and Practices, and their Exposure to Pesticide Residues after Application on the Vegetable and Fruit Crops. Case Study: North of Delta, Egypt. J Environ Anal Toxicol 7(510):
2161-0525.

8. Bempah CK \& Donkor AK (2011). Pesticide residues in fruits at the market level in Accra Metropolis, Ghana, A preliminary study. Environ Monit and Assess 175(1-4): 551-561.

9. Saini RK, Yadav GS \& Kumari B (2014). Novel approaches in pest and pesticide management in agro-ecosystem.

10. Jallow, MF, Awadh, DG, Albaho MS, Devi VY \& Thomas BM (2017). Pesticide knowledge and safety practices among farm workers in Kuwait: results of a survey. Inter $J$ of Environ Res and Pub Heal 14(4): 340.

11. Shalaby, SE, Abdou GY \& Sallam AA (2012). Pesticide-residue relationship and its adverse effects on occupational workers in Dakahlyia, Egypt. Appl Biolog Res 14(1): 24-32.

12. Jafarbeigi F, Samih MA, Zarabi M, \& Esmaeily S (2012). The effect of some herbal extracts and pesticides on the biological parameters of Bemisiatabaci (Genn.)(Hem.:Aleyrodidae) pertaining to tomato grown under controlled conditions. J of Plant Prot Res 52(4): 375-380.

13. Mehrotra S, Kumar S, Zahid M \& Garg M (2017). Bio-pesticides. In Principles and applications of environmental biotechnology for a sustainable future. Springer, Singapore pp 273-292.

14. Adebayo TA (2003). Efficacy of mixture formulations of synthesis and botanical insecticides in the control of insect pests of okra and cowpea. Ph.D. Thesis submitted to Ladoke Akintola University of Technology, Ogbomoso, Nigeria.

15. Babarinde SA, Ogunkeyede AF (2008). $J$ of Ultra Sci of Physical Sci 20(2): 411.

16. Amuji CF, Echezona BC, Dialoke SA (2012). J of Agri and Vet Sci 4: 45-52.

17. Hill DS, Waller JM, (1988). Pests and Diseases of Tropical Crops, Logman, New York, pp 414. 